\title{
Użyteczność badania 18F-FDG PET/CT w diagnostyce guzów pierwotnych i przerzutów nowotworowych do mózgu
}

\section{The utility of the 18F-FDG PET/CT in the primary and metastatic brain lesions diagnosis}

\section{Adrianna Medak ${ }^{6}$, Julia Wojtowicz7 ${ }^{7}$ Katarzyna Pietrasz ${ }^{2}$, Witold Cholewiński ${ }^{3}$, Beata Pisarska ${ }^{2}$, Aleksandra Heydrych ${ }^{1}$, Krzysztof Matuszewski $^{3}$, Hubert Szweda ${ }^{3}$, Patrycja Mantaj ${ }^{1}$, Kamila Urbaniak ${ }^{4}$, Katarzyna Wiecheć ${ }^{5}$, Agata Karolina Pietrzak ${ }^{1}$,}

\footnotetext{
${ }^{1}$ Katedra i Zakład Elektroradiologii Uniwersytetu Medycznego im. K. Marcinkowskiego w Poznaniu ${ }^{2}$ Zakład Medycyny Nuklearnej Wielkopolskiego Centrum Onkologii, Poznań, Polska ${ }^{3}$ Zakład Fizyki Medycznej, Wielkopolskie Centrum Onkologii, Poznań ${ }^{4}$ Pracownia Ochrony Radiologicznej, Wielkopolskie Centrum Onkologii, Poznań ${ }_{5}^{5}$ Katedra i Zakład Psychologii Klinicznej, Uniwersytet Medyczny im. K.Marcinkowskiego w Poznaniu ${ }^{6}$ student kierunku Elektroradiologia, Katedra i Zakład Elektroradiologii, Uniwersytet Medyczny w Poznaniu ${ }^{7}$ student kierunku Lekarskiego, Uniwersytet Medyczny $w$ Łodzi
}

\section{Wstęp}

Badanie pozytonowej tomografii emisyjnej/tomografii komputerowej z zastosowaniem radiofarmaceutyku 2-deoxy-2-[ $\left.{ }^{18} \mathrm{~F}\right]$ fluoro-D-glukozy (z ang. 2-deoxy-2- $\left.{ }^{[18} \mathrm{F}\right]$ fluoro-D-glucose positron emission tomography/ computed tomography, ${ }^{18} \mathrm{~F}-\mathrm{FDG}-\mathrm{PET} / \mathrm{CT}$ ) jest metodą $\mathrm{z}$ wyboru $\mathrm{w}$ diagnostyce licznych chorób onkologicznych. Jednakże, zgodnie z wytycznymi Światowej Organizacji Zdrowia (z ang. World Health Organization, WHO), użyteczność badania PET z zastosowaniem radiofarmaceutyku ${ }^{18} \mathrm{~F}-\mathrm{FDG}$ w ocenie struktur mózgu jest nieznaczna [1,2]. Względnie niska specyficzność metody ${ }^{18} \mathrm{~F}-\mathrm{FDG}$ PET/CT w porównaniu z PET/CT z zastosowaniem innych radiofarmaceutyków w wykrywaniu ognisk nowotworowych w regionie mózgu wynika $\mathrm{z}$ nieswoistego charakteru radiofarmaceutyku ${ }^{18} \mathrm{~F}-\mathrm{FDG} \mathrm{i}$ wysokiego stopnia utylizacji radioznacznika w całej objętości mózgu [3]. Z uwagi na ograniczoną zdolność metody ${ }^{18}$ F-FDG PET/CT do rozróżnienia zmian łagodnych i złośliwych mózgu, struktury położone powyżej poziomu podstawy czaszki, są częstokroć wyłączane z protokołu akwizycyjnego [4].

Adres do korespondencji

Agata Karolina Pietrzak

Katedra i Zakład Elektroradiologii Uniwersytetu Medycznego im. K. Marcinkowskiego w Poznaniu e-mail: agata.pietrzakk@gmail.com 
W wielu pracowniach medycyny nuklearnej na świecie, w tym w Polsce, badanie ${ }^{18}$ F-FDG PET/CT wykonywane jest zwykle w ograniczonym zakresie, wyłączającym obszar mózgu, uzasadniając wybór wskazaniami WHO oraz potencjalnie zwiększonym narażeniem soczewek gałek ocznych na szkodliwe skutki oddziaływania promieniowania jonizującego $[1,4]$. Stosowanie pełnego protokołu akwizycyjnego, obejmującego, zgodnie z wytycznymi towarzystw medycyny nuklearnej, w tym European Association of Nuclear Medicine and Molecular Imaging (EANM), może natomiast skutkować wykryciem zarówno pierwotnych, jak i przerzutowych ognisk w mózgu [5-7]. Bez względu na etiologię, guz mózgu może być przyczyną licznych dolegliwości, takich jak zaburzenia widzenia, równowagi, ból lub paraliż, które wpływają na samopoczucie i zdolności lokomotoryczne chorych [8]. Jako zagrażające życiu i obniżające jakość życia chorych onkologicznie, leczenie guzów mózgu włączane jest zwykle w protokół leczenia onkologicznego [9].

$\mathrm{Z}$ uwagi na wątpliwości klinicystów oraz brak aktualnego piśmiennictwa potwierdzającego lub odrzucającego hipotezę o konieczności ograniczenia skanowania do granicy podstawy czaszki, podjęcie badań wydaje się zasadne.

\section{Cel pracy}

Celem niniejszej pracy jest wykazanie, że mimo nieswoistego charakteru radiofarmaceutyku ${ }^{18} \mathrm{~F}-\mathrm{FDG}$, badanie ${ }^{18} \mathrm{~F}-\mathrm{FDG}$ PET/CT pozwala wykryć guzy pierwotne i przerzuty nowotworowe do mózgu, co może skutkować modyfikacją protokołu terapeutycznego i zwiększeniem skuteczności zastosowanego leczenia, a także - potencjalnie - poprawić jakość życia chorego onkologicznie.

\section{Materiał i metoda}

Treść niniejszej pracy powstała w oparciu o dostępne piśmiennictwo naukowe, związane z zastosowaniem metody ${ }^{18}$ F-FDG PET/CT w diagnostyce guzów mózgu z lat 1997-2019 (włączając wytyczne międzynarodowych towarzystw medycyny nuklearnej) oraz dane oryginalne, dotyczące chorych badanych i leczonych w Wielkopolskim Centrum Onkologii w roku 2012.

Analizie poddano 18 osób, u których wykryto zmiany podejrzane w regionie mózgu (9 kobiet, 9 mężczyzn, średnia wieku \pm odchylenie standardowe; OS; $59 \pm 9$ lat). W grupie znaleźli się chorzy nieleczeni, których poddano badaniu ${ }^{18}$ F-FDG PET/CT z objęciem obszaru: szczyt czaszki - połowa długości kości udowych, celem określenia stopnia zaawansowania choroby (rak płuca - 9 chorych, rak sutka - 6 chorych, guz jajnika - 2 osoby, 1 przypadek nowotworu złośliwego tarczycy). Badanie wykonano po 60 minutach (min; 56 $\pm 4 \mathrm{~min})$ po iniekcji (p.i.) radiofarmaceutyku ${ }^{18} \mathrm{~F}-\mathrm{FDG}$ o aktywności 3,7 megabecquereli/kilogram masy ciała (MBq/ $\mathrm{kg}$ ), wykorzystując porównywalne parametry techniczne akwizycji PET/CT.

W procesie segmentacji i analizy danych wykorzystano oprogramowanie MiM 7.0 (MiM Software Inc. Cleveland, Ohio, Stany Zjednoczone Ameryki). Wymagane pomiary statystyczne przeprowadzono z użyciem aplikacji Statistica (StatSoft, Polska).

Ograniczeniem prezentowanych badań jest struktura analizowanej grupy jako homogennej pod względem wieku i płci. Wśród monitorowanych jednostek chorobowych znalazły się ponadto najczęściej występujące rozpoznania onkologiczne. $\mathrm{Z}$ uwagi na powyższą charakterystykę bazy danych, określenie korelacji statystycznej pomiędzy częstością wykrywania zmian w regionie mózgu a płcią, wiekiem czy rozpoznaniem nie jest zasadne.

\section{Wyniki}

Celem diagnostyki z użyciem metody PET/CT była konieczność określenia stopnia zaawansowania choroby przed rozpoczęciem leczenia. Wśród monitorowanych jednostek chorobowych dominował nowotwór złośliwy płuca i sutka, czyli jedne z najczęstszych rozpoznań onkologicznych. Rozkład statystyczny płci i wieku był rozkładem normalnym, przyjmując poziom istotności o,05.

W każdym przypadku, wyznaczano stopień utylizacji radiofarmaceutyku ${ }^{18} \mathrm{~F}$-FDG orazrozkład przestrzenny aktywności metabolizmu glukozy, wykorzystując wskaźnik dedykowany metodzie PET - standaryzowaną wartość wychwytu obliczaną na podstawie masy ciała chorego (z ang. Standardized Uptake Value in body 
weight, $\mathrm{SUV}_{\mathrm{bw}}$ ). Pomiar SUV nie miał wpływu na modelowanie prezentowanych wyników, służąc jedynie rozróżnieniu tkanki prawidłowej i patologicznie zmienionej w obszarze zainteresowania (z ang. Region of Interest, ROI).

W grupie badanej znaleźli się chorzy z rozpoznaniem raka płuca (9 chorych), sutka (6), a także nowotworu złośliwego jajnika (2) i tarczycy (1 osoba). Analizie aktywności metabolizmu glukozy poddano ognisko pierwotne, określano naciek tkanek sąsiadujących, stopień zaawansowania węzłowego oraz liczbęi lokalizację przerzutów odległych. Szczególnie precyzyjnej ewaluacji poddano 8 przypadków, w których zmiana w regionie mózgu była jedynym widocznym ogniskiem przerzutowym (Ryc.1.-2.). U 7 osób wykryto oligometastazę (liczne przerzuty do węzłów chłonnych, tkanek miękkich i kości). U pozostałych 3, poza ogniskiem w mózgu, stwierdzono nieliczne obszary o podwyższonej aktywności metabolicznej, przede wszystkim naciek tkanek otaczających guz pierwotny, a także przerzuty do węzłów chłonnych.

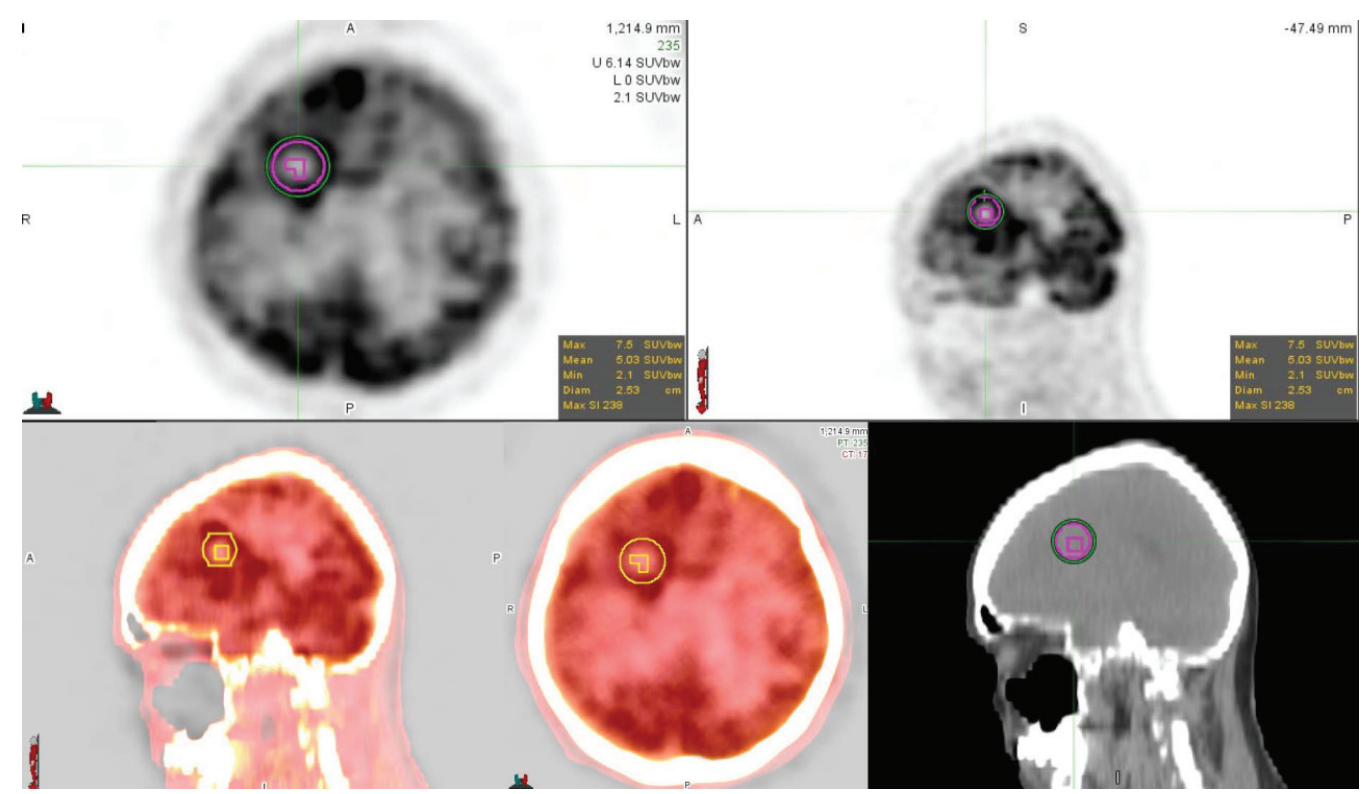

Legenda: górna część ryciny - przekroje PET, u dołu od lewej: fuzja obrazów PET i CT, tomogram CT; kolorem fioletowym oznaczono obszar martwiczy wewnątrz guza, kolorem zielonym - objętość guza; mm-milimetr, cmcentymetr

Ryc.1. Ognisko przerzutowe w mózgu u chorej z rozpoznanym rakiem sutka (źródło: rycina własna)

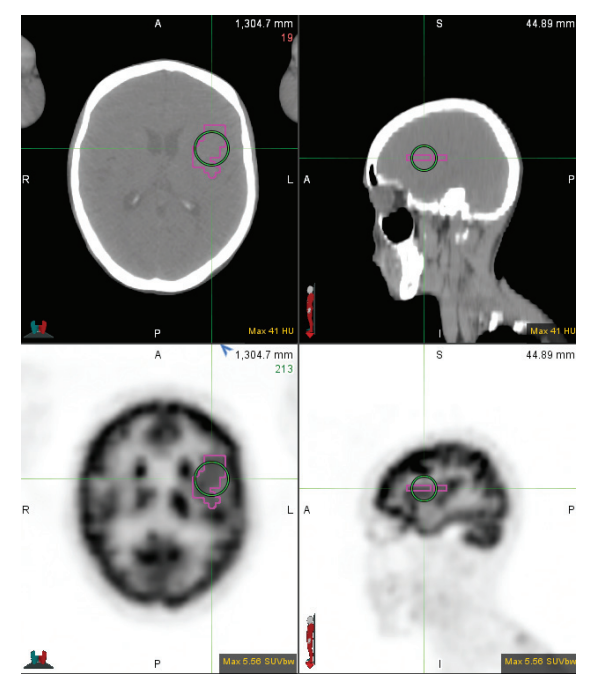

Legenda: u góry ryciny widoczne są przekroje tomograficzne, u dołu - obrazy PET; kolorem fioletowym oznaczono guz, zielonym - obszar najwyższej aktywności metabolicznej

Ryc.2. Przerzut raka płuca do mózgu (źródło: rycina własna) 
Obserwowane zmiany zlokalizowane były przede wszystkim w płatach ciemieniowych (ośrodek czucioworuchowy, odpowiedzialny także za procesy związane z orientacją przestrzenną i koncentracją) lub potylicznym (ośrodek kontrolujący zdolność widzenia i rozróżniania barw). W wybranych przypadkach, zarówno lokalizacja, jak i liczba oraz masa wykrytych guzów wskazywała na prawdopodobieństwo wystąpienia dolegliwości wynikających z zaburzeń neurologicznych.

\section{Dyskusja}

Wśród najczęstszych dolegliwości związanych ze wzrostem masy guza w obszarze mózgu, wyróżnić należy m.in. zaburzenia widzenia, koncentracji i równowagi. Wykrycie guza mózgu, bez względu na etiologię, narzuca konieczność wdrożenia odpowiedniego leczenia zasadniczego (zmiana pierwotna) lub uzupełniającego (ognisko przerzutowe), ponieważ obecność masy w mózgu stanowi zarówno zagrożenie dla życia, jak również może skutkować obniżeniem jakości życia chorego onkologicznie [6,10-11].

Wykrycie zmiany w mózgu jest szczególnie istotne w przypadku, gdy stanowi jedyną widoczną na skanach akwizycyjnych manifestację wysokiego stopnia zaawansowania choroby nowotworowej. Zdolność wybranej metody obrazowej do oceny zaawansowania węzłowego lub stwierdzenie obecności ognisk odległych istotnie ogranicza rozdzielczość przestrzenna techniki. Oznacza to, że zmiany mniejsze niż $5 \mathrm{~mm}$ mogą być nieuchwytne. Jednakże, obecność przerzutu do mózgu jednoznacznie wskazuje na wysoki stopień zaawansowania procesu chorobowego i narzuca konieczność wdrożenia leczenia systemowego, interwencji chirurgicznej lub modyfikacji protokołu radioterapeutycznego [12].

Uwzględniając dotychczasowy stan wiedzy w rozważanym ujęciu, ograniczanie obszaru skanowania $\mathrm{w}$ badaniach ${ }^{18} \mathrm{~F}-\mathrm{FDG}-\mathrm{PET} / \mathrm{CT}$, popierane hipotezą o znacznym narażeniu struktur mózgu i soczewek oczu wywołanym objęciem ww. struktur skanowaniem CT, wydaje się nieprecyzyjne. Dożylna iniekcja radiofarmaceutyku jest źródłem narażenia całego ustroju, przy czym dawka skuteczna, na którą narażony jest ów obszar w trakcie skanowania protokołem niskiej dawki CT, stanowi najpewniej nieistotną statystycznie frakcję całkowitego narażenia ciała chorego, co wymaga jednak dalszych badań.

\section{Wnioski}

Stosowanie pełnego protokołu akwizycyjnego badania ${ }^{18}$ F-FDG PET/CT może skutkować przypadkowym wykryciem zmian złośliwych w obszarze mózgu i potencjalnie zwiększyć efektywność leczenia, a także poprawić jakość życia chorych onkologicznie, poddanych leczeniu uzupełniającemu.

\section{Konflikt interesu / Conflict of interest}

Nie występuje / None

\section{Etyka / Ethics}

Treści przedstawione w artykule są zgodne z zasadami Deklaracji Helsińskiej, dyrektywami EU oraz ujednoliconymi wymaganiami dla czasopism biomedycznych.

\section{Piśmiennictwo}

[1] Dostęp w Internecie: World Health Organization (WHO). Division of Mental Health and Prevention of Substance Abuse. $(\square$ 1997) $\square$. WHOQOL : measuring quality of life. Dostęp w: https://apps.who.int/iris/ handle/10665/63482.

[2] Królicki L, Kunikowska J, Kobylecka M, Mączewska J, Fronczewska K. Znaczenie pozytonowej tomografii emisyjnej (PET) w diagnostyce schorzeń onkologicznych. Postępy Nauk Medycznych 2011;2:104-8.

[3] Almuhaideb A, Papathanasiou N, Bomanji J. ${ }^{18}$ F-FDG PET/CT Imaging In Oncology. Ann Saudi Med. 2011;31:3-13.

[4] Rozporządzenie Ministra Zdrowia z dn. 22.12.2014r. w sprawie ogłoszenia wykazu wzorcowych procedur 
radiologicznych z zakresu medycyny nuklearnej (Dz.Urz.Min.Zdr.z dn. 29.12.2014r. poz.82).

[5] Boellaard R, Delgado-Bolton R, Oyen WJ, Giammarile F, Tatsch K, Eschner W

[6] i wsp. FDG PET/CT: EANM Procedure Guidelines for Tumour Imaging: Version 2.o. Eur J Nucl Med Mol Imaging 2015;42:328-54.

[7] Nagańska E. Objawy neurologiczne guzów mózgu. Postępy Nauk Medycznych 2006;3:112-18.

[8] Abbasain H, Sadeghi R, Emami F, Dabbagh Kakhki VR. ${ }^{18}$ FDG PET/CT in Pulmonary Carcinosarcoma and Brain Metastasis. Asia Ocean J Nucl Med Biol 2019;7:181-4.

[9] Butowski NA. Epidemiology and Diagnosis of Brain Tumors. Continuum (Mineap Minn) 2015;21:301-13.

[10] Lin X, DeAngelis LM. Treatment of Brain Metastases. J Clin Oncol 2015;33:3475-84.

[11] Langegård U, Ahlberg K, Fransson P, Johansson B, Sjovall K, Bjork-Erkisson T i wsp. Evaluation of Quality of Care in Relation to Health-Related Quality of Life of Patients Diagnosed With Brain Tumor: A Novel Clinic for Proton Beam Therapy. Support Care Cancer 2019;27:2679-91.

[12] Urbański B. The role of surgery and radiotherapy in management of breast cancer brain metastases. Letters in Oncology Science 2019;16:23-6.

[13] Rosenfelder N, Brada M. Integrated treatment of brain metastases. Curr Opinion Oncol 2019;31:501-7. 